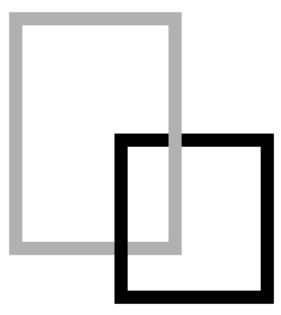

\title{
MIEJSCA PAMIĘCI MNIEJSZOŚCI UKRAIŃSKIEJ NA PODKARPACIU A UPAMIĘTNIENIE ZBROJNEG0 KONFLIKTU NA POGRANICZU POLSKO-UKRAIŃSKIM PO II WOJNIE ŚWIATOWEJ
}

Memorial sites of the Ukrainian minority in the Podkarpacie Region vs. commemoration of the military conflict on the Poland-Ukraine borderland after World War II Grażyna Stojak*

SUMMARY: Memorial sites are a material proof of the Poland-Ukraine military conflict in the Podkarpacie Region, which took place in the years 1944-50. It is here, on the Poland-Ukraine borderland that there is a permanent conflict of interests of the local community of different historical identity. In order to commemorate bloody incidents and numerous victims on both sides memorial sites are erected both in Poland and in Ukraine causing conflicts in the past and present. In the article I have shown the significance of the dependence between the memory of the ethnical community and the specifics of the language of the group, which while aiming at the commemoration of events and memorial sites important for them, do not obey the regulations of Polish law. The analysis of the legal basis for erecting these commemorations shows that there is a need to update the law. The importance of the mental layer in context of the intangible value of the cultural heritage of individual ethnic groups, which is often underestimated, can lead to conflicts that reach beyond the border area becoming conflicts of nationwide or even international concern.

KEYWORDS: cultural heritage of national minorities, military conflict, memorial sites, law, Poland-Ukraine borderland

\section{Konflikt interesów społeczności lokalnych o różnej tożsamości historycznej.}

Pogranicze polsko-ukraińskie i specyfika miejsc pamięci z lat: 1944-50 stały się inspiracją do rozważań nad złożonością problematyki miejsc pamięci społeczności o różnej tożsamości historycznej na pograniczu polsko-ukraińskim w okresie powojennym. Przeanalizowana została na przykładach problematyka pamięci zbiorowej w kontekście relacji z kreatywnością działań wspólnotowej społeczności. Wykazałam zależność pomiędzy pamięcią społeczności etnicznej a specyfiką języka grupy dążącej do upamiętnienia, a także jak ważna jest pamięć indywidualna i jej miejsce $\mathrm{w}$ ramach pamięci zbiorowej. Powszechnie niedoceniana wartość warstwy mentalnej w kontekście wartości niematerialnej dziedzictwa kulturowego, które staje się czynnikiem dominującym w działaniach, doprowadzając w efekcie do współczesnych sytuacji konfliktogennych.

Omówiwszy podstawy prawne odnoszące się do upamiętnień w czasie ich powstania, przedstawiłam problem rekonstrukcji przeszłości przez mniejszość ukraińską w relacji jego kontrowersyjnego odbioru tożsamości regionalnej. Zakodowanie znaczeń w symbolice upamiętnień a rekonstrukcja zdarzeń jako lustro pamięci zbiorowej członków mniejszości ukraińskiej stanowi podstawę konfliktu na pograniczu południowo-wschodnim Polski.

* Grażyna Stojak, Institute of Archaeology, Faculty of Sociology and History, University of Rzeszów https://orcid.org/0000-0002-7503-7356 


\section{Podstawy prawne upamiętnień $\mathrm{i}$ ich analiza}

Analiza podstaw prawnych stanowi punkt wyjścia do zrozumienia narastających konfliktów na tle wznoszonych upamiętnień dla poległych członków UPA, a także bitew oraz czynów związanych z krwawymi zdarzeniami w latach 1939-1949 na Podkarpaciu. Stan prawny, który normuje zagadnienie wznoszenia upamiętnień krwawych konfliktów na pograniczu polskoukraińskim w latach 1939-1949, można podzielić na dwie grupy aktów prawnych. Pierwsza z nich odnosi się do zbiorowej pamięci historycznej i niejako z nią związaną sferą emocjonalnoduchową, zaś druga to akty prawne normujące realne działania przy wznoszeniu upamiętnień, które można nazwać realizacją upamiętnienia w terenie.

Podstawowym aktem prawnym, który przynależy do pierwszej grupy i dotyczy miejsc pochówków oraz ich prawnej ochrony, jest Ustawa o grobach i cmentarzach wojennych $\mathrm{z}$ dnia 28 marca 1933 roku wraz z późniejszymi zmianami¹. (Dz. U. 2017 poz. 681) Zostały one wprowadzone na podstawie Obwieszczenia Marszałka Sejmu Rzeczypospolitej Polskiej z dnia 10 marca 2017 roku w sprawie ogłoszenia jednolitego tekstu ustawy o grobach i cmentarzach wojennych ${ }^{2}$. Pierwsza zmiana została wprowadzona jeszcze przed II wojną światową Dekretem Prezydenta Rzeczypospolitej w dniu 19 listopada 1938 roku33. Dotyczyła ona rozciągnięcia mocy obowiązującej niektórych aktów ustawodawczych na odzyskane ziemie Śląska Cieszyńskiego. Kolejna zmiana została wprowadzona w okresie PRL-u, gdy istniał jeszcze podział administracyjny na 17 województw i dotyczyła ona wprowadzenia przepisów Kodeksu

1 Dz. U. 1933 nr 39 poz. 311- Ustawa z dnia 28 marca 1933 r. o grobach i cmentarzach wojennych. Dz. U. 2017 poz. 681 .

2 Obwieszczenie Marszałka Sejmu Rzeczypospolitej Polskiej z dnia 10 marca 2017 r. w sprawie ogłoszenia jednolitego tekstu ustawy o grobach i cmentarzach wojennych.

Na podstawie art. 16 ust. 1 zdanie pierwsze ustawy z dnia 20 lipca 2000 r. o ogłaszaniu aktów normatywnych i niektórych innych aktów prawnych (Dz. U. z 2016 r. poz. 296 i 1579) ogłasza się w załączniku do niniejszego obwieszczenia jednolity tekst ustawy z dnia 28 marca 1933 r. o grobach i cmentarzach wojennych (Dz. U. Nr 39, poz. 311), z uwzględnieniem zmian wprowadzonych:

- dekretem Prezydenta Rzeczypospolitej z dnia 19 listopada 1938 r. o rozciągnięciu mocy obowiązującej niektórych aktów ustawodawczych na odzyskane ziemie Śląska Cieszyńskiego (Dz. U. Nr 90, poz. 612),

- ustawą z dnia 20 maja 1971 r. - Przepisy wprowadzające Kodeks wykroczeń (Dz. U. Nr 12, poz. 115),

- ustawą z dnia 28 lipca 2005 r. o partnerstwie publiczno-prywatnym (Dz. U. Nr 169, poz. 1420),

- ustawą z dnia 29 lipca 2005 r. o zmianie niektórych ustaw w związku ze zmianami w podziale zadań i kompetencji administracji terenowej (Dz. U. Nr 175, poz. 1462),

- ustawą z dnia 23 czerwca 2006 r. o zmianie ustawy o grobach i cmentarzach wojennych (Dz. U. Nr 144, poz. 1041),

- ustawą z dnia 15 maja 2015 r. o zmianie ustawy o cmentarzach i chowaniu zmarłych, ustawy o grobach i cmentarzach wojennych oraz ustawy o Instytucie Pamięci Narodowej - Komisji Ścigania Zbrodni przeciwko Narodowi Polskiemu (Dz. U. poz. 935),

- ustawą z dnia 29 kwietnia 2016 r. o zmianie ustawy o Instytucie Pamięci Narodowej - Komisji Ścigania Zbrodni przeciwko Narodowi Polskiemu oraz niektórych innych ustaw (Dz. U. poz. 749) oraz zmian wynikających z przepisów ogłoszonych przed dniem 9 marca $2017 \mathrm{r}$.

3 Dekret Prezydenta Rzeczypospolitej z dnia 19 listopada 1938 r. o rozciągnięciu mocy obowiązującej niektórych aktów ustawodawczych na odzyskane ziemie Śląska Cieszyńskiego (Dz. U. Nr 90, poz. 612). 
Miejsca pamięci mniejszości ukrainskiej na Podkarpaciu a upamiętnienie [...]

Wykroczeń ${ }^{4}$ W związku z reformą samorządową Państwa Polskiego wprowadzono trzy kolejne zmiany, z których najważniejszą była Ustawa z dnia 29 lipca 2005 roku o zmianie niektórych ustaw $w$ związku ze zmianami w podziale zadań $i$ kompetencji administracji terenowej, a także Ustawa z dnia 23 czerwca 2006 roku o zmianie ustawy o grobach i cmentarzach wojennych 6 .

Następne zmiany miały miejsce w związku z poszerzeniem działalności Instytutu Pamięci Narodowej oraz zmianami wynikającymi z przepisów ogłoszonych przed dniem 9 marca 2017 roku? $^{7}$.

Kolejnym ważnym aktem prawnym, aczkolwiek o przedwojennym rodowodzie, było Rozporzadzenie Ministra Spraw Wewnętrznych z dnia 23 października 1936 r. (Dz. U. $1936 \mathrm{nr}$ 85 poz. 595) wydane w porozumieniu z Ministrami Spraw Wojskowych i Opieki Społecznej w sprawie wykonania Ustawy z dnia 28 marca 1933 r. o grobach i cmentarzach wojennych. ${ }^{8}$ Powyższe Rozporzadzenie zostało uchylone z dniem 29 kwietnia 2016 roku, w związku ze zmianami ustawy o IPN i powołaniu Komisji Ścigania Zbrodni przeciwko Narodowi Polskiemu. ${ }^{9}$

Ważnym krokiem legislacyjnym było uchwalenie w 1988 roku Ustawy o powołaniu Rady Ochrony Pamięci Walk i Męczeństwa wraz z oddziałami, które funkcjonowały jako oddziały przy urzędach wojewódzkich w całym kraju ${ }^{10}$. Bardzo ważne zobowiązanie dla społeczeństwa zarówno dla inwestorów upamiętnień wszelkiego typu, jak i urzędników wydających pozwolenia - wprowadził art.4 powyższej ustawy, który mówił że:

„Organy właściwe w sprawach wydawania zezwoleń na wykonanie trwałych znaków i obiektów upamiętniających walki i męczeństwo są obowiązane do zasięgnięcia opinii Rady i jej

4 Ustawa z dnia 20 maja 1971 r. - Przepisy wprowadzające Kodeks wykroczeń (Dz. U. Nr 12, poz. 115).

5 Ustawa z dnia 29 lipca 2005 r. o zmianie niektórych ustaw w związku ze zmianami w podziale zadań i kompetencji administracji terenowej (Dz. U. Nr 175, poz. 1462).

6 Ustawa z dnia 23 czerwca 2006 roku o zmianie ustawy o grobach i cmentarzach wojennych. (Dz. U. Nr 144, poz. 1041).

7 Ustawa z dnia 15 maja 2015 r. o zmianie ustawy o cmentarzach i chowaniu zmarłych, ustawy o grobach i cmentarzach wojennych oraz ustawy o Instytucie Pamięci Narodowej - Komisji Ścigania Zbrodni przeciwko Narodowi Polskiemu (Dz. U. poz. 935), Ustawa z dnia 29 kwietnia 2016 r. o zmianie ustawy o Instytucie Pamięci Narodowej - Komisji Ścigania Zbrodni przeciwko Narodowi Polskiemu oraz niektórych innych ustaw (Dz. U. poz. 749).

8 Dz.U. 1936 nr 85 poz. 595, Rozporządzenie Ministra Spraw Wewnętrznych z dnia 23 października 1936 r. wydane w porozumieniu z Ministrami Spraw Wojskowych i Opieki Społecznej w sprawie wykonania ustawy z dnia 28 marca 1933 r. o grobach i cmentarzach wojennych.

Uchylone - Ustawą z dnia 29 kwietnia 2016 r. o zmianie ustawy o Instytucie Pamięci Narodowej - Komisji Ścigania Zbrodni przeciwko Narodowi Polskiemu oraz niektórych innych ustaw.Dz.U. 2016 poz. 749.

Data wejścia w życie - 2016-06-16.

Data obowiązywania - 2016-06-16.

9 Ustawa z dnia 29 kwietnia 2016 r. o zmianie ustawy o Instytucie Pamięci Narodowej - Komisji Ścigania Zbrodni przeciwko Narodowi Polskiemu oraz niektórych innych ustaw. (Dz.U. 2016 poz. 749).

10 Dz.U. 1988 nr 2 poz. 2 - Ustawa z dnia 21 stycznia 1988 r. o Radzie Ochrony Pamięci Walk i Męczeństwa. 
rozpatrzenia przed wydaniem decyzji." ${ }^{11}$ Ustawa ta została uchylona Ustawa z dnia 29 kwietnia 2016 roku o zmianie Ustawy o Instytucie Pamięci Narodowej - Komisji Ścigania Zbrodni przeciwko Narodowi Polskiemu ${ }^{12}$.

Lata 90.XX wieku przyniosły dwa ważne dokumenty rangi międzypaństwowej. Pierwszym z nich był „Traktat między RP a Ukrainą o dobrym sąsiedztwie, przyjaznych stosunkach i współpracy" zawarty 18 maja $1992 \mathrm{roku}^{13}$. Drugi to Umowa między Rzadem Rzeczypospolitej Polskiej a Rzadem Ukrainy o ochronie miejsc pamięci i spoczynku ofiar wojny i represji politycznych, która została sporządzona w Warszawie dnia 21 marca 1994 roku i weszła w życie 29 sierpnia $1994 \mathrm{roku}^{14}$. Kolejnym ważnym dokumentem była Ustawa z dnia 18 grudnia 1998 roku o Instytucie Pamięci Narodowej - Komisji Ścigania Zbrodni przeciwko Narodowi Polskiemu ${ }^{15}$.

Legislację w powyższym zakresie zamyka Obwieszczenie Marszałka Sejmu Rzeczypospolitej Polskiej z dnia 8 września 2016 roku w sprawie ogłoszenia jednolitego tekstu ustawy o Instytucie Pamięci Narodowej - Komisji Ścigania Zbrodni przeciwko Narodowi Polskiemu ${ }^{16}$. W świetle powyższego wykonywanie zadań z zakresu upamiętniania walk i męczeństwa, a także historycznych wydarzeń dla Narodu Polskiego powierzono Instytutowi Pamięci Narodowej. Działalność tę ma prowadzić w kraju i za granicą. Ponadto - zapisano jest także delegacja do wykonywania zadań w zakresie upamiętniania miejsc walk i męczeństwa innych narodów na terenie Rzeczypospolitej ${ }^{17}$.

Ustawa zobowiązuje IPN do wykonywania zadań, które w szczególności dotyczą inicjowania opieki nad miejscami walk i męczeństwa, a także wydarzeń i postaci z nimi związanych. Powyższa opieka dotyczy także cmentarzy i grobów wojennych, miejsc walk narodowowyzwoleńczych, cmentarzy ofiar totalitarnego terroru. W świetle ustawy, IPN powinien angażować się do współdziałania w upowszechnianiu wiedzy na temat wydarzeń związanych z miejscami pamięci oraz organizacji uroczystości dotyczących tych upamiętnień. Szczególną uwagę skupiono na organizacji przez IPN szeroko zakrojonej akcji informacyjnej skierowanej do wszystkich grup społecznych oraz pokoleń, a także oceny stanu opieki nad izbami pamięci narodowej. Wyjątkowo ważną funkcją nałożono na IPN - Komisję Ścigania Zbrodni przeciwko Narodowi

11 J.w, Art.4.

12 Ustawą z dnia 29 kwietnia 2016 r. o zmianie ustawy o Instytucie Pamięci Narodowej - Komisji Ścigania Zbrodni przeciwko Narodowi Polskiemu oraz niektórych innych ustaw. Dz.U. 2016 nr 0 poz. 749.

13 „Traktat między RP a Ukrainą o dobrym sąsiedztwie, przyjaznych stosunkach i współpracy” z 18 maja 1992r.

14 Umowa między Rządem Rzeczypospolitej Polskiej a Rządem Ukrainy o ochronie miejsc pamięci i spoczynku ofiar wojny i represji politycznych, sporządzona w Warszawie dnia 21 marca 1994 r. - weszła w życie 29 sierpnia $1994 \mathrm{r}$.

15 Dz. U. 1998 nr 155 poz. 1016 - USTAWA z dnia 18 grudnia 1998 r. o Instytucie Pamięci Narodowej - Komisji Ścigania Zbrodni przeciwko Narodowi Polskiemu.

16 Dz. U. 2016 poz. 1575, Obwieszczenie Marszałka Sejmu Rzeczypospolitej Polskiej z dnia 8 września 2016 r. w sprawie ogłoszenia jednolitego tekstu ustawy o Instytucie Pamięci Narodowej - Komisji Ścigania Zbrodni przeciwko Narodowi Polskiemu.

17 Art. 53j. 1. 


\section{Miejsca pamięci mniejszości ukraińskiej na Podkarpaciu a upamiętnienie [...]

Polskiemu - w postaci opracowywania opinii pod kątem prawdziwości faktów historycznych $\mathrm{w}$ zakresie ustanowienia trwałego upamiętnienia miejsc pamięci związanych $\mathrm{z}$ walkami i męczeństwem. Udzielono także delegacji dla IPN do współdziałania ze środowiskami na emigracji i organizacjami polonijnymi, w zakresie stałego opiekowania się upamiętnieniami walk i męczeństwa Polaków poza granicami Polski. Szczególnym rodzajem utrwalania pamięci o faktach związanych z walkami i męczeństwem Narodu Polskiego jest stosowanie trwałych form dla uczczenia powyższych wydarzeń. Ponadto w sprawach miejsc pamięci związanych z walkami, grobami, cmentarzami i męczeństwem, które mogą mieć wpływ na politykę państwa, Prezes IPN ma prawo do podejmowania działań wraz z ministrem właściwym do spraw kultury i ochrony dziedzictwa narodowego.

Od dnia 1 sierpnia 2016 roku w kompetencjach IPN jest „zajmowanie stanowisk, wydawanie opinii oraz występowanie $\mathrm{z}$ wnioskami $\mathrm{w}$ sprawach opieki nad miejscami walk i męczeństwa oraz trwałego upamiętniania związanych $\mathrm{z}$ tymi miejscami faktów, wydarzeń i postaci."18 Ponadto: „Organy właściwe w sprawach wydawania zezwoleń na wykonanie trwałych znaków i obiektów upamiętniających walki i męczeństwo wydają zezwolenie po zasięgnięciu opinii Prezesa Instytutu Pamięci." Przepis wszedł w życie z dniem 1 sierpnia 2016 roku $^{19}$.

Akty prawne dotyczące bezpośredniej realizacji upamiętnień stanowią drugą grupę aktów prawnych. Według Ustawy Prawo budowlane z 1974 roku, na budowę pomników, kapliczek, obiektów kultu religijnego, posągów i innych monumentów małej architektury na cmentarzach i przykościelnych terenach, nie było wymagane pozwolenie na budowę $e^{20}$. Przepisy te zostały uchylone w ponad dwadzieścia lat później, Ustawą Prawo budowlane z dnia 7 lipca 1994 r²1.

Zgodnie z nowymi unormowaniami prawnymi Ustawy Prawo budowlane z dnia 7 lipca 1994 roku aby wznieść upamiętnienie w sposób legalny, zgodnie z prawem należało stosować określone przepisami procedury ${ }^{22}$.Zgodnie z wymienionymi wyżej unormowaniami prawnymi, w przypadku gdy planowane było wznoszenie upamiętnienia w obrębie cmentarza, należało uzyskać zezwolenie wojewody na „wznoszenie pomników i innych urządzeń na cmentarzach i grobach wojennych". ${ }^{23}$ Konieczne było również uzyskanie opinii o treści przedmiotowego upamiętnienia, które powinno być wydane przez Wojewódzki Komitet Ochrony Pamięci Walk i Męczeństwa przy Urzędzie Wojewódzkim. W przypadku, gdy upamiętnienie było

18 J. w., Art. 53k.

19 J. w., Art. 531.

20 Dz.U. 1974 nr 38 poz. 229 - Ustawa z dnia 24 października 1974 r. Prawo budowlane. Dz.U. 1975 Nr.8 poz.48 - Rozporządzenie Ministra Gospodarki Terenowej i Ochrony Środowiska z dnia 20 lutego 1975 r. w sprawie nadzoru urbanistyczno-budowlanego.

21 Uchylone - Ustawą z dnia 7 lipca 1994 r. - Prawo budowlane. Dz.U. 1994 Nr 89 poz. 414. Data uchylenia:1995-01-01; \$19 ust. 2 - Uzyskanie pozwolenia na budowę nie wymaga budowa pomników, posągów, kapliczek i innych podobnych obiektów kultu religijnego na terenach cmentarzy i terenach przykościelnych, związanych z wykonywaniem kultu religijnego.

22 Dz.U. $1994 \mathrm{nr} 89$ poz. 414 Ustawa z dnia 7 lipca 1994 r. - Prawo budowlane.

23 J.w. 
wznoszone poza obszarem cmentarza, należało zastosować się do procedur wynikających z Ustawy Prawo budowlane. W przypadku, gdy teren, obszar architektoniczno-urbanistyczny lub obiekt cmentarza, na którym planowana była realizacja upamiętnienia, objęty był nadzorem konserwatora zabytków z tytułu indywidualnego wpisu do rejestru zabytków bądź objęcia go ochroną poprzez wpis obszaru urbanistyczno-architektonicznego, wymagano uzgodnienia $\mathrm{z}$ urzędem konserwatorskim i potwierdzenia go otrzymaniem zezwalającej decyzji od wojewódzkiego konserwatora zabytków.

Dodatkowo, po 1 stycznia 1995 roku, czyli po wejściu w życie nowej Ustawy Prawo Budowlane, realizacja upamiętnienia w przypadku zakwalifikowania go jako obiektu małej architektury, wymagała zgłoszenia inwestycji organowi nadzoru budowlanego.

Powyższe ustalenia prawne i związane z tym wymogi uległy zmianie po 1 sierpnia 2016 roku czyli po zmianie ustawy o IPN i przyjęciu nowej. Wówczas realizacja trwałych znaków oraz obiektów upamiętniających walki i męczeństwo, wymagała uzyskania opinii Prezesa Instytutu Pamięci Narodowej.

3. Wznoszenie nielegalnych upamiętnień dla uczczenia pamięci UPA jako zarzewie konfliktów polsko-ukraińskich po 1989 roku.

Upamiętnienia związane z czczeniem pól bitewnych, szpitali, bunkrów, miejsc niewoli i śmierci członków UPA na Podkarpaciu, które zostały wzniesione bez spełnienia wymogów określonych przepisami prawa, zostały uznane za nielegalne. Pomimo, że ustalone zostały w Polsce metody i formy postępowania, na przełomie XX i XXI wieku bez uzyskania wymaganych pozwoleń wzniesiono upamiętnienia w hołdzie dla działalności UPA. Powstały one w „miejscach pamięci” związanych ze zbrojnym konfliktem polsko-ukraińskim po II wojnie światowej, które są ważne dla społeczności ukraińskiej zamieszkałej w Polsce. Wzniesiono je w latach 90.XX wieku i w początkach XXI wieku bez uzgodnień, o których mówią przepisy prawa. Stały się punktem sporów lokalnych, a następnie zarzewiem konfliktów wykraczających poza Podkarpacie. Upamiętnienia te wniesiono w miejscowościach położonych na Roztoczu: Monasterz, Werchrata, Lubliniec Nowy, Lubliniec Stary. Kolejne, wzniesione bezprawnie na terenie Ziemi Przemyskiej w miejscowościach: Hruszowice, Małkowice, Kalników i Leszno, wywołały konflikty regionalne, które szybko stały się ogólnopolskim ogniskiem niezgody, a następnie międzynarodowym zatargiem politycznym, wyrosłym na podłożu upamiętnień.

Gdy w pierwszej połowie lat 90. XX wieku powstały upamiętnienia na Roztoczu, nikt nie spodziewał się takiego rozmiaru zatargów o podłożu nacjonalistycznym. Dwa z wyżej wymienionych upamiętnień powstały w miejscowościach: Monasterz i Werchrata. M.in.: zostało uczczone miejsce pamięci w miejscowości Monasterz w ówczesnym województwie przemyskim. W 1994 r. wybudowany został pomnik ku czci poległych członków Ukraińskiej Powstańczej Armii bez posiadania pozwolenia na rozpoczęcie prac budowlanych. Wzniesione zostało upamiętnienie, które nie było zaopiniowanie przez wojewódzkiego konserwatora zabytków w Przemyślu. Zostało to uznane za przestępstwo $\mathrm{z}$ art. 90 Ustawy Prawo budowlane $\mathrm{z}$ dnia 7 


\section{Miejsca pamieci mniejszości ukraírskiej na Podkarpaciu a upamiętnienie [...]}

lipca $1994 \mathrm{r}^{24}$ Analogicznie jak poprzednie upamiętnienie, kolejne powstało na cmentarzu komunalnym w Werchracie w gminie Horyniec na Roztoczu, gdzie uczczono miejsce pamięci związane z UPA przez wzniesienie pomnika zwieńczonego krzyżem ze znakiem tryzuba. Oprócz symboli znajdują się płyty z inskrypcjami oraz nazwiskami osób, które poniosły w tym miejscu śmierć. Mimo wymogu zasięgania opinii na temat zasadności wzniesienia upamiętnienia i użycia narodowych symboli, tablic i tekstów upamiętniających wydarzenie, przed rozpoczęciem robót nie zwracał się do Rady Ochrony Pamięci Walk i Męczeństwa. Fakt te został przytoczony jako argument łamania prawa i zasad, które ustalono. Ponadto nie uzgodniono także wykazu osób biorących w nim udział. Powszechnie podnoszono fakt o działaniu poza ustalonymi zasadami i nie liczeniu się z obowiązującym prawem. Nagłośniono także istotę sporu pomiędzy stroną polską a przedstawicielami mniejszości ukraińskiej w Polsce, która dotyczy ignorancji wytycznych polskiego rządu, gdyż nikt nie wystąpił o wydanie opinii na temat merytorycznego uzgodnienia treści wykorzystywanych $\mathrm{w}$ upamiętnieniu ${ }^{25}$. Upamiętnienia te były wielokrotnie niszczone przez nieznanych sprawców i odbudowywane przez organizatorów ze strony ukraińskiej, co przekształciło się w permanentny konflikt interesów zwaśnionych stron.

O wiele bardziej nabrzmiałym konfliktem były upamiętnienia na terenie Ziemi Przemyskiej. Najgłośniejszy z nich, który zapisał się na arenie międzynarodowej w stosunkach polskoukraińskich, było upamiętnienie powstałe w Hruszowicach w gminie Stubno w powiecie przemyskim.

Inicjatorembudowypomnikaomonumentalnejformiebramyna cmentarzuwHruszowicach byłZwiązek Ukraińskich Więźniów Politycznych Okresu Stalinowskiego z siedzibą w Koszalinie. W 1993 roku powstał projekt pomnika, którego nie przedłożono do uzgodnienia. Pomnik zbudowano w 1994 r. na dwóch sąsiadujących ze sobą grobach, bez wymaganych pozwoleń administracyjnych. Akcja związana z potajemnym postawieniem tego pomnika wzbudzała liczne kontrowersje od samego początku. W dniu 20 kwietnia 1995 r. podjęta została uchwała przez Wojewódzki Komitet Ochrony Pamięci Walk i Męczeństwa w której stwierdzono, że pomniki m.in.: w Kalnikowie i Werchracie, a zwłaszcza w Hruszowicach powinny zostać rozebrane. Niebawem też zostały wydane stosowne decyzje o rozbiórce przez organa nadzoru budowlanego. Aczkolwiek dokumenty zostały sporządzone, to przez 20 lat nie były wdrożone ustalenia w nich zawarte i legalnych rozbiórek nie dokonano. Natomiast permanentnie były niszczone powyższe upamiętnienia $\mathrm{w}$ aktach dewastacji niewolnych od nacjonalistycznych zabarwień. Ostatecznie, w 2017 roku pomnik w Hruszowicach został rozebrany zgodnie $\mathrm{z}$ wydaną decyzją, niemniej jednak towarzyszyła temu atmosfera międzynarodowego skandalu.

Wymienione powyżej upamiętnienie $\mathrm{w}$ Kalnikowie, związane jest $\mathrm{z}$ działalnością grupy mieszkańców, która nie była wysiedlona z tych terenów w ramach Akcji „Wisła”. Samowolnie, działając z determinacją wyrównano historyczny kurhan ziemny, który istniał na lokalnym cmentarzu. Celem tej dewastacji było utworzenie miejsca pamięci oznaczonego

24 Art. 90 Ustawy Prawo budowlane z dnia 7 lipca 1994 r. (Dz.U nr 89, poz. 41 z późn. zm.

25 Przytaczam za: A. Zapałowski: Nacjonalizm ukrainski w Polsce - trend czy zaplanowana polityka? (http:// geopolityka.net//andrzej-zapalowski-nacjonalizm-ukrainski-w-polsce-trend-czy-zaplanowana-polityka/) 
krzyżem, pod którym wmurowana została tablica z symbolem tryzuba i napisem w języku ukraińskim. Wszystkie działania, napisy i inskrypcje nie posiadały pozwoleń urzędowych. Wzbudziło to wielką falę protestów. W dyskusjach podnoszono m.in.: egzekwowanie innych rozbiórek samowoli budowlanych, przyrównując do powyższych upamiętnień. Braki takie jak brak pozwolenia na budowę i uzgodnień z Podkarpackim Wojewódzkim Konserwatorem Zabytków w Przemyślu doprowadzily do eskalacji problemu regionalnego do rangi konfliktu ogólnokrajowego, z odzwierciedleniem w tych problemów w ogólnopolskich mediach.

W opinii wojewódzkiego inspektora nadzoru budowlanego podnoszony był fakt, że powstanie pomników na grobach członków UPA było niezgodne z obowiązującą ustawą z dnia 28 marca 1933 r. o grobach i cmentarzach wojennych (Dz.U. z 30 maja 1933 r.), zwłaszcza art. 5 i art. 9 tej ustawy, a także $₫ 2$ ust. 1 rozporządzenia ministra spraw wewnętrznych z 23 października 1936 r. (Dz.U. z 7 listopada 1936 r.), które nakładają obowiązek uzyskania przez inwestora zezwolenia wojewody na „wznoszenie pomników i innych urządzeń na cmentarzach i grobach wojennych". Również nie zastosowano się do procedury wynikającej z ustawy z dnia 21 stycznia 1988 r. o Radzie Ochrony Pamięci Walk i Męczeństwa (DzU z 1988 r. nr 2) dotyczącej w szczególności art. 3, który mówi o obowiązku wyrażenia opinii o treści upamiętnienia przez Wojewódzki Komitet Ochrony Pamięci Walk i Męczeństwa. W związku z tym, że inwestor nie zwracał się o wydanie takiej opinii, uznano fakt za ignorancję zasad wznoszenia upamiętnień, które zostały ustalone przez polski rząd.

Biorąc pod uwagę przytoczone wyżej fakty, można stwierdzić, że upamiętnienia wzniesione przed 1 stycznia 1995 r., mimo że nie wymagały pozwolenia na budowę, to jednak zostały wzniesione niezgodnie $\mathrm{z}$ obowiązującym prawem. Odnośnie do pomników wybudowanych po wejściu w życie Ustawy Prawo budowlane, które powstały z naruszeniem obowiązującego w RP prawa, należało podjąć procedurę zmierzającą do rozbiórki obiektów. W niektórych przypadkach procedura taka została przeprowadzona, jednak nie wszędzie.

Osobnym zagadnieniem jest łamanie przyjętej zasady o dwujęzycznych napisach na upamiętnieniach. Prawie we wszystkich przypadkach upamiętnienia ukraińskie na pograniczu południowo - wschodniej Polski posiadały napisy wyłącznie w języku ukraińskim. Ponieważ było to niezgodne z uchwałą Rady Ochrony Pamięci Walk i Męczeństwa z 25 stycznia 1995 roku, dochodziło do aktów unicestwiania tych tablic, wzniecając przy tym lokalne konflikty ${ }^{26}$. Przykładem takiej sytuacji może być Leszno, gdzie na terenie przylegającym do parafii greckokatolickiej z siedzibą w Przemyślu znajduje się krzyż, obok którego usytuowany jest niewielki blok betonowy, obecnie nic nie mówiący. Jeszcze w maju 1997 r. na bloku była przymocowana tablica o treści w języku ukraińskim: „Wszystkim tragicznie zamordowanym i wygnanym z ojczystej ziemi oraz poniżonym na skutek akcji Wisła - Parafianie wioski Poździacz". Tablica ta została rozbita, a następnie w czerwcu 1997 r. całkowicie usunięta. Podobna sytuacja wystąpiła na cmentarzu we wsi Małkowice pod Przemyślem, gdzie znajduje się metalowy krzyż, a przed nim

26 Uchwała nr 1 Rady Ochrony Pamięci Walk i Męczeństwa z 25 stycznia 1995 r. w sprawie niezgodnych z obowiązującymi przepisami prawa upamiętnień ukraińskich na obszarze Rzeczypospolitej Polskiej informującej o tym, że napisy powinny być dwujęzyczne. 


\section{Miejsca pamięci mniejszości ukrainskiej na Podkarpaciu a upamiętnienie [...]

płyta umieszczona na zbiorowej mogile w 1991 roku. Na płycie znajduje się wykaz nazwisk osób pochodzenia ukraińskiego, a także napisy w języku ukraińskim upamiętniające pomordowanych w nocy z 17 na 18 kwietnia 1945 roku. Gdyby napisy na płycie były dwujęzyczne, nie byłoby przyczyny do licznych interwencji w tej sprawie.

W większości nie są spełniane wymogi określone Ustawa Prawo Budowlane, aby doprowadzić do zalegalizowania obiektów wybudowanych przed 1 stycznia $1995 \mathrm{r}$. Dlatego próby legalizacji spotkały się z odmową. Wydanie pozytywnej decyzji o udzieleniu zgody na użytkowanie upamiętnień w miejscach pamięci ważnych dla mniejszości ukraińskiej w Polsce, nie było możliwe, gdyż łamane były zasady ustalone przez Radę Ochrony Pamięci Walk i Męczeństwa w Polsce.

Wnioskizostałyzawartew piśmie podsekretarza stanu w Ministerstwie Spraw Wewnętrznych i Administracji z 22.03.2001 r., który pokazuje stan faktyczny istniejący u progu XXI wieku. Od 2001 roku, pomimo przejęcia decydującej roli przez IPN w sprawie upamiętnień, w zakresie powstałych upamiętnień omawianego konfliktu zbrojnego, niewiele zaszło faktycznych zmian. Nadal niektóre upamiętnienia były i są dewastowane, co skutkuje cyklicznym odnawianiem przez inwestorów. W efekcie stanowi to nadal zarzewie stałych konfliktów. Jedyna faktyczną zmianą jest fakt rozbiórki monumentalnego pomnika-bramy w Hruszowicach, do której doszło w 2017 roku. Proces ten uznano za skandal w stosunkach polsko-ukraińskich, a także za skandal dyplomatyczny i złamanie zasad w przygranicznych stosunkach pomiędzy dwoma sąsiadującymi krajami. W ten sposób odebrano i oceniono nakaz rozbiórki upamiętnienia w Hruszowicach, do którego doszło w kilkanaście lat od jego wydania dokumentu administracyjnego.

\section{Podsumowanie i wnioski końcowe.}

Nielegalne upamiętnienia stanowią $\mathrm{i}$ będą stanowić punkt zapalny w stosunkach polsko - ukraińskich, jeśli nie nastąpią radykalne działania normujące. Jest to poważny problem o podłożu zaszłości historycznych w stosunkach Polski i Ukrainy. W chwili obecnej nie istnieją konkretne działania rządowe o długofalowym okresie procedowania. Ich celem powinna być analiza istniejących już upamiętnień oraz interpretacja miejsc pamięci polsko-ukraińskiego konfliktu zbrojnego na pograniczu Polski południowo-wschodniej po II wojnie światowej, o które upomina się społeczność ukraińska. W przedmiotowej owej lustracji - upamiętnień według poniżej wyszczególnionych wykazów, w których są także upamiętnienia działań OUNUPA - wiodącym tematem rozważań powinna być relacja dwóch komponentów: materialnego i niematerialnego, ze szczegółowym omówieniem znaczenia danego miejsca w procesie kreacji miejsca historii! Interpretacja miejsc pamięci powinna nastąpić nie tylko ważnych dla dziejów mniejszości etnicznej, ale przede wszystkim (!) dla historii kraju, na terenie którego utworzenie upamiętnienia jest planowane.

Budowa miejsca pamięci poprzez określenie jego autentyzmu oraz tożsamości kulturowej musi być przeanalizowana z każdej perspektywy, gdyż miejsce historii to miejsce, w których zapisana jest pamięć. Znaczenie pamięci zbiorowej w procesie utrwalania tożsamości nie było dotychczas czynnikiem dostatecznie docenionym jako element konfliktów etnicznych. 
Dopiero od niedawna niektórzy badacze stosunków polsko-ukraińskich na pograniczu wschodnim, z dr hab. Andrzejem Zapałaowskim na czele, analizują problematykę pamięci zbiorowej w zestawieniu z kreatywnością działań wspólnotowej społeczności, zwłaszcza młodych, wchodzących w dorosłość pokoleń. Narracja członków społeczności zbiorowej, a także fakty zapamiętane i przez nich przechowywane są obecnie zbierane i zapisywane przez badaczy, z dużym zaangażowaniem ludzi młodych. Sytuacja ta występuje po każdej ze stron skonfliktowanych. Pamięć społeczności, a specyfika języka grupy nie jest przedmiotem dostatecznych analiz, dlatego jest problemem społecznym wraz z interpretacją danych miejsc pamięci.

Z perspektywy miejsc i pamięci zbiorowej na bazie konfliktu zbrojnego społeczności polskiej i ukraińskiej, w chwili obecnej nie jest możliwe tworzenie miejsc historii, bez wyprzedzających i wyczerpujących rozważań pomiędzy obiema stronami konfliktu. Nadal poruszane są fakty, że upamiętnienia mniejszości ukraińskiej nie odpowiadają nastrojom miejscowej ludności, która przechowuje pamięć o zbrodniach OUN - UPA popełnionych na Polakach, nie chce tych miejsc pamięci i broni się przed nimi. Podnoszone są także coraz częściej kwestie, że państwo przyzwalające na swoim terytorium do upamiętnień wrogich sobie organizacji, które dopuściły się masowego ludobójstwa Polaków, naraża się na lekceważenie na arenie międzynarodowej.

W wyniku wstępnych badań na temat upamiętnień jako repozytoriów pamięci zbiorowej In situ, rozpoznano 98 polskich upamiętnień oraz 84 ukraińskie upamiętnienia konfliktu pogranicza polsko-ukraińskiego wlatach 1939-1947. Bezsprzecznie najliczniejsze upamiętnienia po obu stronach powstały $\mathrm{w}$ dawnym województwie przemyskim i dawnym województwie krośnieńskim.

\section{Rozpoznano następujące upamiętnia polskie (98 obiektów):}

1. Powiat Bieszczadzki: Czarnej, Jureczkowej, Ustrzykach Dolnych, Lutowiskach, Mucznem, Polanie, Ropience, Ustrzykach Dolnych (3), Wojtkowej

2. Powiat Brzozowski: w Grabownicy Starzeńskiej, Temeszowie, kilka obiektów w Brzozowie.

3. Powiat Jarosławski: w Chotyńcu, Jarosławiu (3), Michałówce, Radymnie,

4. Powiat Krośnieński: w Jasielu, Woli Niżnej,

5. Powiat Leski: w Baligrodzie (8), Cisnej (2), Lesku, Bezmiechowej Górnej, Jabłonkach, Eubnie

6. Powiat Leżajski: w Tarnawcu

7. Powiat Lubaczowski: w Cieszanowie (2), Horyńcu Zdroju, Hucie Różanieckiej, Lipsku, Lubaczowie(5), Łowczy, Narolu, Niwki -las, Nowym Bruśnie (2), Nowym Siole, Nowinach Horynieckich, , Rudzie Różanieckiej, Rudce, Starym Lublińcu,

8. Powiat Przemyski: w Birczy (3), Borownicy, Dubiecku (2), Kalwarii Pacławskiej, Krasiczynie, Krzywczy, Kuźminie, Nakle, Żohatynie, Przemyśl - miasto (10),

9. Powiat Rzeszowski: w Dylągowej, Dynowie, Pawłokomie, Rzeszów - miasto (2).

10. Powiat Sanocki: Falejówce, Komańczy, Lisznej,Nowosielcach, Trepczy, Woli Michowej, Zagórzu, Sanok - miasto (5). 
Miejsca pamięci mniejszości ukrainskiej na Podkarpaciu a upamiętnienie [...]

\section{W wyniku badań wstępnych rozpoznano następujące upamiętnienia ukrainskie (84):}

1. Powiat Bieszczadzki: w Krywem, Trzciańcu, Tworylnem

2. Powiat Brzozowski: w Hroszówce, Huta - Poręby, Wołodzi, Woli Wołódzkiej,

3. Powiat Jarosławski: w Chotyńcu, (2), Jarosławiu -miasto, Łazach (2), Mołodyczy, Surmaczówce, Surochowie, Zaleskiej Woli, Zapałowie,

4. Powiat Krośnieński: w Zyndranowej

5. Powiat Leski: $w$ Terce

6. Powiat Leżajkki: w Piskorowicach (3)

7. Powiat Lubaczowski: w Gorajcu, Kobylnicy Wołoskiej, Monasterzu (4), Radrużu, Nowym Lublińcu (3), Starym Siole, Starym Dzikowie, Starym Lublińcu (2), Suchej Woli, Werchracie

8. Powiat Przemyski: w Bachowie, Berendowicach, Brzeżawie, Brzusce, Cisowej, Gajach, Hruszowicach, Jaworniku Ruskim (2), Kalnikowie (2), Kormanicach, Korytnikach, LeszniePoździaczu, Małkowicach, Nowych Sadach, Olszanach, Podbukowinie, Roztoce, Skopowie, Przemyśl - miasto (4), Średniej (2), Torkach

9. Powiat Przeworski: w Dobrej (3), w Dobczy

10. Powiat Rzeszowski: w Pawłokomie

11. Powiat Sanocki: W Chryszczatej, Komańczy (3), Lalinie, Mokrem, Morochowie, Radoszycach, Sanoczku, Smolniku, Wisłoku Wielkim, Zawadce Morochowskiej.

Na wyżej wskazanych terenach nie są prowadzone żadne analizy pod kątem definicji miejsc pamięci z punktu widzenia dziedzictwa kulturowego, ani nie ma interpretacji miejsc pamięci pod kątem relacji komponentów materialnych i niematerialnych. Opracowane zasady i formy ochrony miejsc pamięci w omawianym konflikcie nie są przestrzegane, co starałam się wykazać w powyższym omówieniu zagadnienia. Brak jest również analizy warstw kulturowych miejsc historii z myślą o przyszłości.

Jako Przemyślanka i osoba znająca Podkarpacie, która przez 7 i pół roku pełniła funkcję Podkarpackiego Wojewódzkiego Konserwatora Zabytków w Przemyślu, nigdy nie miałam problemów w prowadzeniu rozmów z każdą (!) ze skonfliktowanych stron i pozostaję z nimi do dziś w dobrych relacjach. Wielokrotnie wypowiadałam się na ten temat publicznie. ${ }^{27}$ Jest to dowód na to, że można rozmawiać o trudnych sprawach i można je analizować. Problem jest jednak w tym, że nikt $z$ osób decyzyjnych na szczeblu rządowym tych rozmów nie podejmuje, a tematów trudnych takich jak kwestia upamiętnień omawianego konfliktu polsko - ukraińskiego nie analizuje. Rozpatrzenie powyższej tematyki powinno być według trzech grup zagadnień i założeń sformułowanych w ramach konferencji „Miejsce Pamięci - definicja, Interpretacja, Ochrona", w dniach 4-5 grudnia 2017 roku.

27 G. Stojak, Wpływ nielegalnych upamiętnień UPA na stan bezpieczeństwa wewnętrznego Polski, wystąpienie (referat) w ramach programu Międzynarodowej Konferencji Naukowej pt.: „Współczesna polityka bezpieczeństwa - aspekty militarne i społeczno-gospodarcze" w Rzeszowie, Uniwersytet Rzeszowski, w dniach 17-18 października 2017 r.; tekst referatu został złożony do druku. 


\section{6}

Grażyna Stojak

Takim przykładem jest upamiętnienie krwawych rozbojów polsko-ukraińskich w Pawłokomie, gdzie w odwecie za zamordowanie kilkunastu Polaków, brutalnie zabito 365 ukraińskich mieszkańców Pawłokomy przez tzw. „Oddziały Wacława”, złożone z byłych żołnierzy Armii Krajowej $w$ dniu 3 marca 1945 roku $^{28}$. Wydarzenia te zostaty uczczone 13 maja 2006 roku przez rzadowe władze polskie i ukraińskie, zaś słowa które wówczas padły, sa powszechnie szanowane do dziś. W uroczystościach wzięli udział prezydenci państw: Lech Kaczyński (Polska) i Wiktor Juszczenko (Ukraina); obaj prezydenci byli znaniz tego, że otwarcie bronili krajów przed spuścizna komunistyczna i odznaczali się kultywowaniem patriotycznych wartości. Swoja postawa podkreślili dążenia do dobrych i pokojowych stosunków pomiędzy współczesną Polską a obecna Ukrainą ${ }^{29}$.

Powyższe przesłanie powinno być argumentem do dalszych rozmów, analiz komponentu materialnego i niematerialnego przed wyrażeniem zgody na powstanie Miejsca Pamięci lub wydanie decyzji o jego rozbiórce.

28 B. Osadczuk, Pawłokoma pojednania (z dnia 14 maja 2006 roku), „WPROST.pl” https://www.wprost. pl/90024/Pawlokoma-pojednania, dostęp z dnia 31.05.2017 r.

29 G. Stojak, „Wplyw nielegalnych upamiętnień UPA na stan bezpieczeństwa wewnętrznego Polski”, referat pokonferencyjny, złożony do druku, zob. przyp. nr 27. 